Білоус Руслана

кандидат психологічних наук, доцент завідувач кафедри психології, педагогіки та філософії

Кременчуцького національного університету імені Михайла Остроградського https://orcid.org/0000-0003-3524-7823

Сошенко Світлана

кандидат педагогічних наук, доцент доцент кафедри психології, педагогіки та філософії Кременчуцького національного університету імені Михайла Остроградського https://orcid.org/0000-0002-5634-2945

Лебединська Ганна кандидат політичних наук, доцент доцент кафедри психології, педагогіки та філософії Кременчуцького національного університету імені Михайла Остроградського https://orcid.org/0000-0001-9320-6240

DOI https://doi.org/10.35619/praprv.v1i16.212

\title{
СОЦІАЛЬНО-ПСИХОЛОГІЧНИЙ ТРЕНІНГ ЯК ЗАСІБ ПОДОЛАННЯ КОМУНІКАТИВНИХ БАР'СРІВ У ПРОЦЕСІ МІЖОСОБИСТІСНОГО СПІЛКУВАННЯ СТУДЕНТІВ
}

\begin{abstract}
Анотація. У статті здійснено узагальнення й систематизацію сучасних підходів до проблеми спілкування, міжособистісного спілкування та подолання комунікативних бар'єрів y студентів. Визначено, щзо міжособистісне спілкування здійснюється за допомогою невербальних та вербальних впливів, спрямоване на утворення більш тісних психологічних зв'язків між учасниками. Виокремлено його функиї: установлення нових контактів, досягнення порозуміння між партнерами по спілкуванню, вплив на емочійні стани партнера, покращення організації спільної діяльності. Розкрито поняття, сутність, особливості, причини виникнення та иляхи попередження $i$ подолання комунікативних бар'єрів. Визначено, щзо комунікативні бар'єри у спілкуванні можуть виникати через сукупність різних сочіальних та психологічних факторів. Запропоновано їх класифікацію та окреслені шляхи їх ефективного подолання у процесі сочіально-психологічного тренінгу, що передбачає знайомство з учасниками, створення сприятливих умов для роботи групи, вироблення правил групової діяльності; роботу з емочійною складовою комунікативного процесу, набуття навичок розпізнання та прояву емоцій; зі стратегіями захисту у процесі спілкування, уміння їх розпізнати, виявлення їх впливу на появу перешкод у комунікацї; із комунікативною толерантністю, визначенням ї̈ важливості у подоланні комунікативних бар'єрів, оволодіння навичками комунікативної толерантності.

Ключові слова: спілкування, міжособистісне спілкування, комунікативні бар'єри: фонетичний, семантичний, стилістичний, логічний, смисловий.

Постановка проблеми. Спілкуванняв житті людини відіграє дуже велику роль, а його психологічна природа надто складна. Завдяки комунікації, мовному спілкуванню, людина формує себе як особистість, опановує і перетворює соціальне та природне середовище, узгоджує вчинки і діяльність з іншими соціальними суб'єктами, формує оточення, виявляє себе іншим, утверджує власне «Я», доводить свою позицію, поведінку, впливає на інших.
\end{abstract}


Однією із основних складових успішного навчання та набуття практичних навичок 3 обраної спеціальності для студентства є комфортне міжособистісне спілкування в процесі професійної підготовки. Перешкоди на шляху адекватної передачі інформації визначаються індивідуальними особливостями учасників спілкування, їх умінням розуміти думки співрозмовника, слухати і концентрувати увагу. Дослідження та подолання комунікативних бар'єрів сприяє ефективності процесу спілкування, швидшому досягненню мети, покращенню соціальної взаємодії, уникненню конфліктів.

Аналіз останніх досліджень 3 проблеми. Проблема подолання комунікативних бар'єрів досить широко розглядалася у вітчизняних і зарубіжних дослідженнях, що дозволило трактувати спілкування як головне джерело життєдіяльності i розвитку особистості, адже саме у спілкуванні здійснюється сприймання та розуміння між людьми, формуються засоби комунікації, такі прояви, як імітація, навіювання, засвоєння соціальних норм, традицій тощо (Морозов, 2000).

Виникнення спілкування як психологічного феномену зумовило його вивчення. Зокрема, в античні часи спілкування сприймалося філософами виключно як інтелектуальне явище, засноване на передачі думок і знань. Таке розуміння питання комунікацій було недосконалим, уривчастим і до кінця не показувало суті спілкування в складній системі людських відносин. У середньовічній філософії проблематика спілкування розглядалася в межах релігійного світогляду, тому для спілкування були характерні принцип духовних змін особистості людей, які спілкуються; зростання єдності людей через духовність (наведено за Філоненко, 2008). В епоху Відродження поняття спілкування стає гуманістичним, а питання комунікацій висвітлювалося в художніх творах Боккаччо, Петрарки, В. Шекспіра, які створили чуттєво-розумову модель людського спілкування, засновану на ідеях активної самореалізації людини, свободи волі, моральності, любові, підкріпленої принципами доброти, рівності, гармонії (Рогов, 2001). В епоху Просвітництва виникли поняття: симпатія, внутрішній діалог особистості. На початку XIX ст. Шлейєрмахер розробив розгорнуту концепцію людського буття як міжособистісного спілкування, у матеріалістичній концепції Фейєрбах розкриває сутність людини через спілкування, єдність «Я» і «Ти», вважаючи спілкування тільки природою спільноти людей (наведено за Орбан-Лебрик, 2004). У XX ст. Бехтерєв визначив, що «чим різноманітніше і багатше спілкування людини з оточуючими, тим успішніше здійснюється розвиток особистості» (наведено за Рубінштейн, 2004, с. 381). Мясищев досліджував формування особистості та іiі відносини під впливом досвіду спілкування з найближчим і значущим соціальним оточенням, розглядаючи спілкування цілісно, як процес взаємодії конкретних особистостей. У зв'язку з цим він говорив про єдність взаємодії між людьми і взаємин між ними, зумовлених нагромаджуваними в ході взаємодії враженнями та переживаннями (наведено за Рубінштейн, 2004).

Проблемі спілкування значну увагу приділяв Ананьєв (2010), розглядаючи спілкування як специфічний вид діяльності з головною його характеристикою - функцією побудови соціальних відносин між людьми, визначаючу соціальну детермінацію онтогенезу особистості та психічний розвиток загалом. В енциклопедичному словнику «спілкування» визначається як передача інформації у будь-якій формі від однієї особи до іншої безпосередньо або за допомогою засобів різних зв'язку. Міжособистісне спілкування як взаємодія між декількома людьми, здійснювана за допомогою засобів вербального і невербального впливу, у результаті якої виникає психологічний контакт і певні відносини між учасниками спілкування (Левін, 2000). Фетискін, Козлов, Мануйлова виділили критерії, за яких взаємодія між людьми є міжособистісною: у спілкуванні бере участь невелика кількість людей (група із 2-3 осіб); це безпосередня взаємодія: учасники знаходяться у просторовій близькості; особистісно-орієнтований характер спілкування, кожен учасник спілкування враховує емоційний стан, особистісні характеристики, унікальність особистості партнера (наведено за Козирєв, 2014). Коломинський підкреслював, що міжособистісне спілкування за нормальних умов соціального та психічного розвитку не може оминути жодного представника соціуму. Автор виділив такі функції міжособистісної взаємодії: контактна - встановлення контакту між партнерами по спілкуванню як стану сумісної 
готовності до прийому і передачі повідомлень; інформаційна - обмін повідомленнями, поглядами, задумами, рішеннями; спонукальна - стимуляція активності партнера для виконання ним певних дій; координаційна - взаємне орієнтування і узгодження дій при організації колективної діяльності; функція розуміння - адекватне сприймання і розуміння смислу повідомлень, а також однакове розуміння намірів, установок, переживань, станів; емоційна функція - пробудження у партнера емоційного переживання стану іншого партнера, зміна при цьому власних переживань і станів; функція встановлення відносин усвідомлення і фіксація свого місця в системі рольових, статусних, ділових та інших зв'язків у суспільстві, в якому індивід здійснює свою діяльність; функція впливу - зміна стану, поведінки, особистісно-смислових утворень партнера (наведено за Рогов, 2001). Перешкоди у спілкуванні є істотним фактором, що зменшує його ефективність та погіршує загальну результативність діяльності людини, міжособистісні стосунки та емоційний стан в цілому. Бар'єр (франц. «barriere») - перешкода у процесі діяльності, поведінки особистості в діяльності відмічається в багатьох дослідженнях, але, зазвичай побіжно, серед багатьох інших чинників: утрудненого спілкування, взаємонерозуміння, труднощів діяльності тощо.

Аналіз концепцій психоаналітичного напрямку показує, що бар'єри інтерпретуються як стан напруги, породжені недостатньо усвідомлюваними внутрішньоособистісними конфліктами, природа яких криється в системі взаємин людини з оточуючим світом, порізному задовольняє іiі базові соціальні потреби. Комунікативні бар'єри (Андреєва, Глазкова) - це перешкоди на шляху адекватної передачі інформації між партнерами зі спілкування; розрізняють комунікативні бар'єри соціального і психологічного характеру, що можуть виникати через відсутність розуміння або внаслідок індивідуальних психологічних особливостей, особливих психологічних відносин між партнерами зі спілкування: неприязні, недовіри один до одного (Глазкова, 2011).

У наукових дослідженнях визначають декілька різних класифікації комунікативних бар'єрів. Зокрема, Орбан-Лембрик (2004) виокремлює такі види бар'єрів: фонетичний, семантичний, стилістичний, логічний, смисловий. Крисько виділяє соціально-культурний бар'єр, зумовлений соціальними, політичними, релігійними, етнічними, професійними, віковими, гендерними відмінностями, котрі породжують різне розуміння понять, які люди використовують у процесі спілкування, а також ці відмінності викликають різне світорозуміння (наведено за Козирєв, 2014). Однак, будь-яка комунікація - це інформаційний, ціннісний, емоційний вплив, у випадку успіху якого можуть відбутися зміни у світогляді, думках, ставленнях того, кому комунікація адресована. Але не всі люди сприймають цей вплив, бажають змін, тому захищаються. Тому Поршнєв виділив три види контрсугестії: уникнення, авторитет і нерозуміння (наведено за Левін, 2000). Корнеліус, Фейр до комунікативних бар'єрів відносять провокатори спілкування: погрози, що обумовлюють образу, страх, ворожість; накази, вказівки, розпорядження, що спричинюють аналогічні відчуття; негативна критика спрямована на людину; прізвиська, навішування ярликів; слова-«боржники»; приховування важливої інформації, яка негативно впливає і на особистісне, і на ділове спілкування; вживання реплік-пасток з емоційними оцінками, які не містять конкретну інформацію; похвала з пасткою; діагноз мотивів поведінки; негативний діагноз мотивів поведінки та інші, що негативно впливають на процес спілкування (наведено за Трофімов, Рибалка, Гончарук, 2006). За іншою класифікацією причинами бар'єрів у спілкуванні можуть бути: компетентність у питанні, щодо якого відбувається розмова, вибірковість слухання, оціночне судження партнера, достовірність джерела інформації, іiі фільтрування (Філоненко, 2008), Розглядаючи проблему бар'єрів спілкування, Морозов (2000, с. 127) звертає увагу на наявність або відсутність таких їх різновидів :

- інформаційно-дефіцитарний бар'єр (механічний обрив інформації, унаслідок чого відбувається перекручування, неясність передавання інформації, у силу чого спотворюється викладена і передана думка);

- заміщувально-спотворювальний бар'єр (надання іншого значення переданим словами). 
Виникнення бар'єрів може бути пов'язано як з психологічними причинами, так і 3 причинами іншого порядку: фонематичні нерозуміння (через похибки в самому каналі передачі інформації внаслідок спілкування на різних мовах, істотних дефектів мовлення та дикції, спотвореного граматичного ладу мови, невиразністю мови); семантичний бар'єр нерозуміння (пов'язаний 3 відмінностями в системах значень (тезаурусах) учасників спілкування - проблема жаргонів і сленгів). Для особистості, нездатної подолати бар'єри, характерні переживання, пов'язані 3 переоцінкою можливої невдачі і недооцінювання можливості задоволення потреби; зростання сили негативних емоцій, погіршення функціонування; загальна незбалансованість психофізіологічної організації. Це викликає послаблення конструктивних тенденцій у психіці людини, розумне планування діяльності втрачає своє значення або зникає зовсім. Деструктивна або пасивна стратегія виявляється у психологічному захисті, відмові від продуктивного розв'язання критичних ситуацій, будьяких спроб усунути обумовлені ситуацією труднощі, зняття емоційної напруги і збереженні уявної цілісності особистісної структури. При реалізації афективно-агресивної стратегії відсутня гнучкість, що ускладнює пошуки позитивних варіантів подолання бар'єрів.

У межах даного дослідження комунікативні бар'єри розглядаються як перешкоди, що виникають у процесі спілкування та заважають ефективності спілкування та діяльності. Вони виникають у всіх сферах комунікації, погіршуючи емоційний стан студентів, психологічний клімат у колективі, знижуючи загальну ефективність виконуваної діяльності. Причини комунікативних бар'єрів можуть мати соціальний чи психологічний характер: соціальні причини пов'язані з різним соціальним статусом комунікуючих, а психологічні причини полягають у різниці мислення, відторгненні людей з порушеннями мови, наданню різного змісту словам.

Як відомо, вікові межі юнацького періоду - від 16 до 25 років. У цей період хлопці та дівчата отримують соціальний статус здобувача освіти, коли активний процес оволодіння знаннями 3 обраної професії відбувається у супроводі комунікації з одногрупниками та викладачами. Саме в студентів спостерігаються дві протилежні тенденції в спілкуванні:

- розширення сфери спілкування і зростаюча індивідуалізація, відокремлення (збільшення часу, який витрачається на спілкування, істотне розширення його соціального простору, географії спілкування) і особливий феномен «очікування спілкування» - пошук та постійна готовності до контактів. У юності особливо зростає потреба як у новому досвіді, так і визнанні, захищеності, в інтимній реакції. Це й визначає зростання потреби у спілкуванні, потреби бути прийнятим і відчувати впевненість та визнання.

- тенденція до індивідуалізації та відособлення (суворе розмежування природи взаємин з оточуючими, висока вибірковість у дружніх прихильностях, часом максимальна вимогливість до спілкування в діаді). В основі відособленості - прагнення захисту власної унікальності, її збереження із бажанням подальшого визнання, що дозволяє дистанціюватися при спілкуванні (Орбан-Лембрик, 2005).

У комунікаціях між викладачем і студентами в якості перешкод і бар'єрів можуть виступати статусні відмінності між ними, або бажання чути тільки те, що хочеться почути. Основні бар'єри в комунікаціях між студентом та викладачем - це складність змісту повідомлення; незвичність і складність форми повідомлення; проблеми із засобами передачі повідомлення; низький зворотний зв'язок; запізнення інформації (Глазкова, 2011). Отже, причинами виникнення комунікативних бар'єрів у студентської молоді є різні емоційні стани та емоційні реакції учасників спілкування; різниця у віці учасників комунікації; різні моральні цінності співрозмовників; відсутність симпатії у комунікуючих; різні потреби, інтереси, мотиви. На спілкування у студентів витрачається більше часу, воно стає ближчим, допомагає виділити свою індивідуальність. Перешкоди у комунікації виникають 3 однолітками і з викладачами, вони проявляються в нерозумінні змісту повідомлень, нетерпимості до людей з вадами мови, цькуванні студентів 3 іншим соціальним статусом, різниці у віці, етносі тощо. 
Мета статті. Вивчення психологічних особливостей прояву комунікативних бар'єрів у студентському середовищі; розробка та впровадження програми соціально-психологічного тренінгу, спрямованого на профілактику та подолання комунікативних бар'єрів.

Виклад основного матеріалу дослідження. Дослідження проводилося у Кременчуцькому національному університеті імені Михайла Остроградського. Для дослідження сформовано вибірку із 145 студентів різних груп, що активно беруть участь у навчальному процесі та житті студентської групи. Вибірка створювалася при використанні стратегії рандомізації і $є$ репрезентативною.

Зі студентами проведено бесіду для отримання інформації про міжособистісну комунікацію та комунікацію в межах закладу освіти в цілому, що дозволило визначити методики для експерименту. При плануванні та організації експерименту враховано методологічний, методичний і технологічний аспекти (чітку фіксацію початкових умов, можливих результатів, контрольза змінами, фіксацію умов та результатів), що гарантує валідність експерименту.

У дослідженні використано методики, які дають змогу здійснити дослідження комунікативних бар'єрів у студентів: адаптовану під студентську молодь анкету «Комунікативні бар'єри в організації» (авт. Карамуша), діагностики «перешкод» у встановленні емоційних контактів (авт. Бойко), діагностики домінуючої стратегії психологічного захисту у спілкуванні (авт. Бойко), діагностики комунікативної установки за (авт. Бойко).

Узагальнення результатів емпіричного дослідження дозволило встановити, що комунікативні перешкоди характерні для 42 \% респондентів. Найчастіше бар'єри виникають 3 викладачами $(37,7 \%)$, $з$ адмістрацією факультету (33, \%). Більшість опитаних вважають, що перешкоди у спілкуванні не мають впливу на успішність їхньої діяльності (40\%). Переважаючими причинами виникнення перешкод є різні моральні цінності (40\%), різниця мотивів $(32,8 \%)$ та емоційних станів $(28,9 \%)$. У якості профілактики комунікативних бар'єрів студенти обрали індивідуальну консультацію (60 \%) та соціально-психологічний тренінг (42,2\%).

За методикою виявлення «перешкод» у встановленні емоційних контактів спостерігається наявність деяких емоційних перешкод (40 \%) та ускладнення комунікативної взаємодії у 33,4 \% респондентів, домінуючі перешкоди: небажання до зближення на емоційному рівні $(31,1 \%)$, негнучкість емоцій $(24,4 \%)$ та домінування негативних емоцій $(22,2$ \%). При 3'ясуванні домінуючої стратегії захисту у спілкуванні встановлено, що стратегія миролюбства характерна для $51,1 \%$ респондентів, уникнення - для $31,1 \%$ та агресії - для 17,8\%. У студентської молоді домінує середній рівень комунікативної толерантності (62,2\%); домінуючими поведінковими факторами є бажання підлаштувати людину під себе, зробити зручною в комунікації; нездатність до приховування негативних емоцій.

Таблиия 1

\section{Рівні вияву поведінкових показників комунікативної толерантності}

\begin{tabular}{|l|c|c|c|}
\hline \multicolumn{1}{|c|}{ Показники комунікативної толерантності } & \multicolumn{3}{|c|}{$\begin{array}{c}\text { Кількісні показники підгруп різного } \\
\text { рівня ком. толерантності (у \%) }\end{array}$} \\
\cline { 2 - 4 } & низький & середній & високий \\
\hline Неприйняття індивідуальності інших людей & 13,3 & 73,4 & 13,3 \\
\hline Оцінка людей у порівнянні з собою & 37,8 & 53,3 & 8,9 \\
\hline $\begin{array}{l}\text { Консерватизм та категоричність при оцінці } \\
\text { партнера по спілкуванню }\end{array}$ & 42,2 & 48,9 & 8,9 \\
\hline $\begin{array}{l}\text { Невміння приховати негативні почуття 3 } \\
\text { некомунікабельним співрозмовником }\end{array}$ & 20 & 70,1 & 8,9 \\
\hline
\end{tabular}




\begin{tabular}{|l|c|c|c|}
\hline $\begin{array}{l}\text { Прагнення переробити, перевиховати партнера } \\
\text { по спілкуванню }\end{array}$ & 18,4 & 53,3 & 28,3 \\
\hline $\begin{array}{l}\text { Бажання зробити партнера зручним у } \\
\text { комунікації }\end{array}$ & 43,4 & 28,3 & 28,3 \\
\hline Невміння пробачати помилки & 20 & 66,7 & 13,3 \\
\hline $\begin{array}{l}\text { Нетерпимість до фізичного або психічного } \\
\text { дискомфорту партнера по спілкуванню }\end{array}$ & 53,4 & 40 & 6,6 \\
\hline $\begin{array}{l}\text { Погане пристосування до характерів, звичок } \\
\text { інших }\end{array}$ & 17,7 & 55,6 & 26,7 \\
\hline
\end{tabular}

Проведене дослідження ступеня тісноти зв'язку між якісними номінальними ознаками за допомогою коефіцієнту взаємної зв'язаності ознак Крамера V (V1 = 0,228, p $\geq 0,05$; V2 = $0,281, \mathrm{p} \geq 0,05 ; \mathrm{V} 3=0,27, \mathrm{p} \geq 0,05)$ дозволило встановити відсутність статистично значущої асоціативної залежності між домінуючою стратегією психологічного захисту в спілкуванні та рівнями комунікативної толерантності; між домінуючої стратегією психологічного захисту в спілкуванні та рівнями прояву емоційних перешкод; рівнями прояву емоційних перешкод та комунікативної толерантності.

Отримані результати зумовили розробку програми соціально-психологічного тренінгу для профілактики та зменшення впливу комунікативних бар'єрів у студентської молоді. За Максименком (2005), тренінг трактується як навчання, виховання, тренування, що показує різноманітність інтерпретації: навчання, в основу результатів якого покладено точність психодіагностики та вміння цілісного аналізу поведінкової продукції; процес набуття знань, умінь, поведінкових навиків; засіб впливу для розвитку знань, соціальних установок, умінь та досвіду в міжособистісному спілкуванні; практика психологічного впливу, що базується на активних методах групової роботи; емоційно насичене заняття, спрямоване на зміни, гармонізацію стилю спілкування особистості, прищеплення бажаних навиків і вирішення протиріч, які виявляються при взаємодії з іншими людьми, мають внутрішньо особистісний характер; програма, зорієнтована на створення можливостей для розвитку професійно важливих якостей, необхідних для успішної діяльності в екстремальних умовах, готовності до подальшого особистісного зростання і самовдосконалення (Максименко, 2005).

Найбільш ефективною груповою формою роботи для профілактики та подолання комунікативних бар'єрів у студентському віці є метод соціально-психологічного тренінгу, зорієнтований на використання активних методів групової психологічної роботи з метою розвитку соціально-психологічної компетентності. Для досягнення мети тренінгу створено умови для формування групи високого рівня розвитку, що забезпечується принципами організації тренінгових занять, зорієнтованих на профілактику та подолання комунікативних бар'єрів: активністю досліджуваних, дослідницькою позицією, об'єктивацією поведінки, партнерським спілкуванням. Для профілактики та подолання комунікативних бар'єрів студентів застосовували групову дискусію; ситуаційно-рольові, ділові ігри; медитативні техніки, психогімнастику.

3 метою перевірки ефективності запропонованого соціально-психологічного тренінгу, зі студентами, у яких на констатувальному етапі були виявлені певні труднощі у встановленні контактів 3 іншими людьми, до та після тренінгу була проведена методика «Діагностики перешкод у встановленні емоційних контактів». Ї̈̈ результати подано на рисунку 1. 


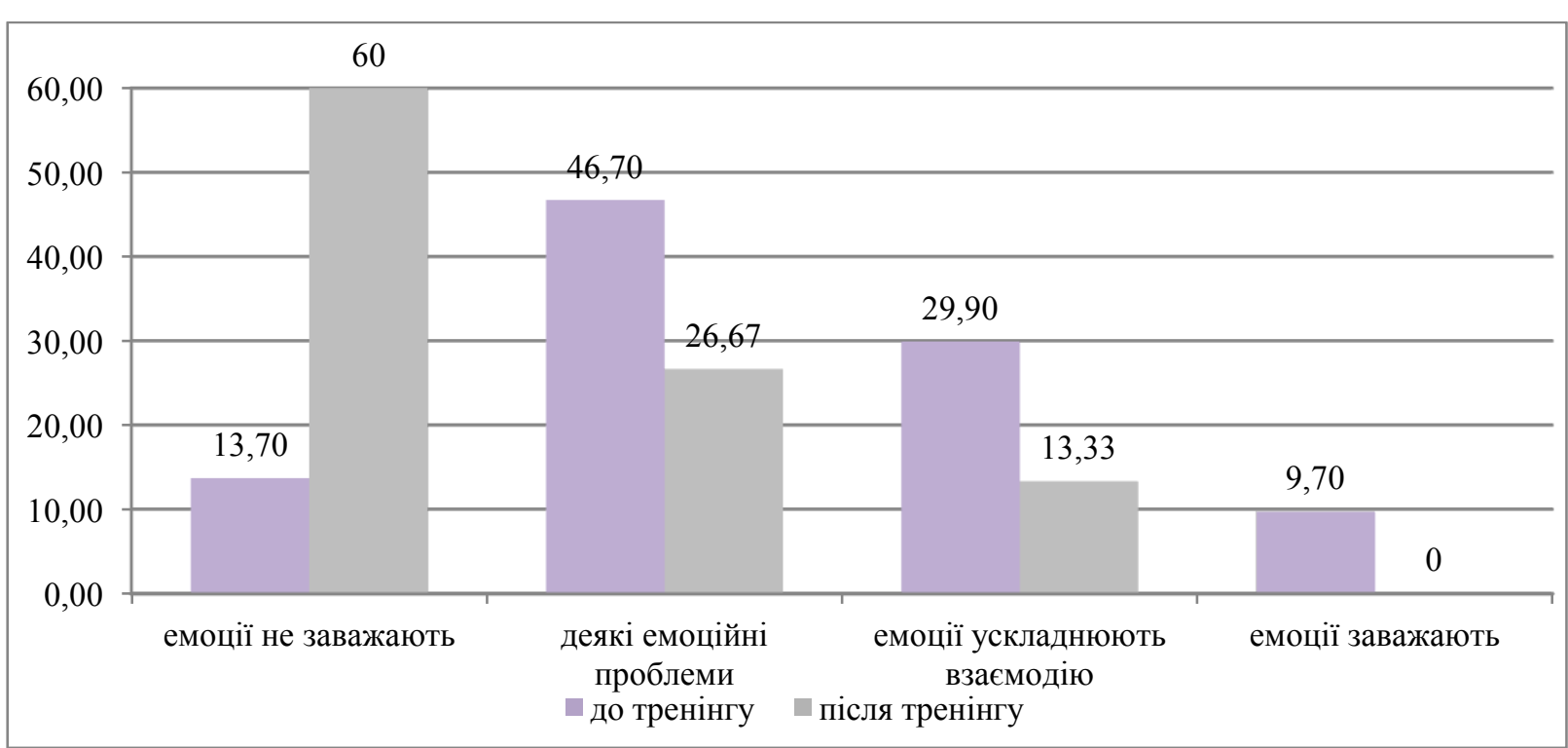

Рис. 1. Порівняння проявів емоційних перешкод до та після проведення соціальнопсихологічного тренінгу

За методикою «Визначення домінуючої стратегії психологічного захисту в спілкуванні» 53,3 \% студентів схильні до стратегії миролюбності, 33,3\% - уникають комунікативних конфліктів та 13,3 \% обрали агресивну психологічну стратегію захисту. Порівняння домінуючих стратегій психологічного захисту до та після проведення тренінгу надано в таблиці 2.

Таблиия 2

\section{Порівняння домінуючих стратегій психологічного захисту}

\begin{tabular}{|l|c|c|c|}
\hline \multirow{2}{*}{ Домінуюча стратегія захисту } & \multicolumn{3}{|c|}{ Кількісні показники вияву стратегій (у \%) } \\
\cline { 2 - 4 } & миролюбність & уникнення & агресія \\
\hline до тренінгу & 26,7 & 40 & 33,3 \\
\hline після тренінгу & 53,3 & 33,3 & 13,4 \\
\hline
\end{tabular}

Отже, внаслідок соціально-психологічного тренінгу студенти частіше використовують стратегію миролюбства (53,3 \%); менше - стратегії уникнення та агресії, що свідчить про ефективність тренінгової програми, спрямованої на ознайомлення зі стратегіями психологічного захисту у комунікації та їх впливом на появу перешкод у спілкуванні. Після проведення тренінгу відсутній низький рівень комунікативної толерантності, середній рівень характерний для 66,7 \% респондентів та 33,3\% мають високий рівень комунікативної толерантності. Для підтвердження ефективності розробленої програми соціальнопсихологічного тренінгу отримані дані проаналізовано за допомогою методів математичної статистики (t-критерій Стьюдента). Аналіз порівняння параметрів досліджуваних до та після проведення експерименту засвідчує наявність статистично значущих змін показників рівня емоційних перешкод у комунікації $\left(\mathrm{t}_{\mathrm{r}}=10,2\right)$ та рівню комунікативної толерантності $\left(\mathrm{t}_{\mathrm{r}}=6,0\right)$ після проведення тренінгу на рівні значущості $\mathrm{p} \leq 0,01$. Отже, після проведення тренінгу значно зменшилися показники рівню емоційних перешкод у спілкуванні студентів, що підтверджує ефективність розробленої програми психокорекційних заходів щодо профілактики емоційних перешкод у спілкуванні.

Висновки i перспективи подальших розвідок. Спілкування $\epsilon$ одним iз найважливіших процесів для людини, що дозволяє передавати й сприймати інформацію, об'єднуватися в соціальні групи та виконувати складну діяльність. Міжособистісне спілкування здійснюється при використанні вербального та невербального впливів, у 
результаті чого виникає психологічний контакт і встановлюються відносини між його учасниками, вплив на емоційний стан партнера, здійснюється координація діяльності, розуміння співрозмовників.

Подолання комунікативних бар'єрів у студентів ефективне у процесі соціальнопсихологічного тренінгу на таких рівнях: навчання прийомам і методам зниження рівня впливу чинників виникнення бар'єрів; розширення функціональних та операціональних можливостей особистості, формування необхідних навичок, умінь, знань, які ведуть до прийняття коректної стратегії комунікативної поведінки; ознайомлення з різними типами поведінки в соціумі.

Перспективами подальших досліджень $є$ вивчення гендерних і вікових особливостей комунікативних бар'єрів у студентів.

\section{СПИСОК ПОСИЛАНЬ}

Ананьев, Б. (2010). Человек как предмет познания. Санкт-Петербург: Питер.

Глазкова, І.Я. (2011). Комунікативні бар'єри: сутність, причини появи, типологія. Слов'янськ: Гуманізація навчально-виховного процесу.

Козирєв, М. П. (2014). Комунікативні бар'єри спілкування та шляхи їх подолання. Львів: Науковий вісник.

Левин, К. (2000). Разрешение социальных конфликтов. Санкт-Петербург: Речь.

Максименко, С. Д. (2005). Технологія тренінгу. Київ: Главник.

Морозов, А. В. (2000). Деловая психология. Санкт-Петербург: Союз.

Орбан-Лембрик, Л. Е. (2004). Соціальна психологія. Київ: Либідь.

Рогов, Е. И. (2001). Психология общения. Москва: ВЛАДОС.

Рубинштейн, С. Л. (2006). Основы общей психологии. Санкт-Петербург: Питер.

Трофімов, Ю. Л., Рибалка, В. В., \& Гончарук, П. А. (2006). Психологія. Київ: Либідь.

Філоненко, М. М. (2008). Психологія спілкування. Київ: Центр учбової літератури.

\section{REFERENCES}

Ananyev, B. (2010). Chelovek kak predmet poznaniya [Human as a subject of cognition]. SanktPeterburg: Piter. [In Russian].

Glazkova, I. Ya. (2011). Komunikativni bar'eri: sutnist, prichini poyavi, tipologiya [Communication barriers: essence, causes, typology]. Slov'yansk: Gumanizatsiya navchalno-vikhovnogo protsesu. [in Ukrainian].

Kozirev, M. P. (2014). Komunikativni bar'eri spilkuvannya ta shlyakhi ïkh podolannya [Communication barriers and ways to overcome them]. Lviv: Naukoviy visnik. [in Ukrainian].

Levin, K. (2000). Razresheniye sotsialnykh konfliktov [Resolution of social conflicts]. SanktPeterburg: Rech. [in Russian].

Maksymenko, S. D. (2005). Tekhnolohiia treninhu [Training technology]. Kyiv: Hlavnyk. [in Ukrainian].

Morozov, A. V. (2000). Delovaya psikhologiya [Business psychology]. Sankt-Peterburg: Soyuz. [in Russian].

Orban-Lembryk, L. E. (2004). Sotsialna psykholohiia [Social psychology]. Kyiv: Lybid. [in Ukrainian].

Rogov, E. I. (2001). Psikhologiya obshcheniya [Psychology of communication]. Moskva: VLADOS. [in Russian].

Rubinshteyn, S. L. (2006). Osnovy obshchey psikhologii [Fundamentals of general psychology]. Sankt-Peterburg: Piter. [in Russian].

Trofimov, Yu. L., Ribalka, V. V., \& Goncharuk, P. A. (2006). Psikhologiya [Psychology]. Kyiv: Libid. [in Ukrainian].

Filonenko, M. M. (2008). Psikhologiya spilkuvannya [Psychology of communication]. Kyiv: Tsentr uchbovoï literaturi. [in Ukrainian]. 


\title{
SOCIAL AND PSYCHOLOGICAL TRAINING AS A MEANS OF OVERCOMING COMMUNICATIVE BARRIERS IN THE PROCESS OF STUDENTS' INTERPERSONAL COMMUNICATION
}

\author{
Ruslana Bilous \\ Candidate of Psychological Sciences, Associate Professor \\ Head of the Department of Psychology, Pedagogy and Philosophy \\ https://orcid.org/0000-0003-3524-7823
}

Svetlana Soshenko

Candidate of Pedagogical Sciences, Associate Professor Associate Professor of Psychology, Pedagogy and Philosophy https://orcid.org/0000-0002-5634-2945

Anna Lebedynska Candidate of Political Science, Associate Professor Associate Professor of Psychology, Pedagogy and Philosophy Kremenchuk Mykhailo Ostrohradskyi National University https://orcid.org/0000-0001-9320-6240

DOI https://doi.org/10.35619/praprv.v1i16.212

\begin{abstract}
The article summarizes and systematizes modern approaches to the problem of communication, interpersonal communication and overcoming communication barriers among students. It is determined that interpersonal communication is carried out through non-verbal and verbal influences, aimed at forming closer psychological connections between the participants. Its functions are distinguished: establishing new contacts, achieving understanding between communication partners, influencing the emotional state of the partner, improving the organization of joint activities. The concept, essence, features, characteristics, causes and ways to prevent and overcome communication barriers are revealed. It has been determined that communication barriers in communication can arise due to a combination of different social and psychological factors. Their classification is offered and some ways of their effective overcoming in the process of social and psychological training are outlined, which provides acquaintance with the participants, creation of favorable conditions for group work, elaboration of rules of group activity; work with the emotional component of the communicative process, acquiring skills of recognition and expression of emotions; with protection strategies in the process of communication, the ability to recognize them, identifying their impact on the emergence of barriers to communication; with communicative tolerance, determining its importance in overcoming communication barriers, mastering the skills of communicative tolerance.

Modern psychology offers a wide arsenal of methods of active cognition and influence on the psyche of the individual to help in difficult conditions of dynamic life. Overcoming communication barriers is effective in the process of socio-psychological training at the following levels: learning techniques and methods to reduce the level of influence of barriers; expansion of functional and operational capabilities of the individual, the formation of the necessary skills, abilities, knowledge, which lead to the adoption of a correct strategy of communicative behavior; acquaintance with different types of behavior in society.
\end{abstract}

Key words: communication, interpersonal communication, communicative barriers: phonetic, semantic, stylistic, logical, semant. 